THE RAÍZES DA PRAIA COMMUNITY: AN EXPERIENCE OF INSURGENT PRACTICES IN FORTALEZA, BRAZIL

\title{
COMUNIDADE RAÍZES DA PRAIA: UMA EXPERIÊNCIA DE PRÁTICAS INSURGENTES NA CIDADE DE FORTALEZA
}

\author{
Clarissa Sampaio Freitas ${ }^{1}$ \\ Manuela Teixeira Arias ${ }^{2}$ \\ Rachel Teixeira Rocha ${ }^{3}$ \\ Lina Garcia de Figueiredo ${ }^{4}$ \\ Ana Carolina de A. Salas Roldan ${ }^{5}$ \\ Virgínia Nascimento ${ }^{6}$
}

\section{ABSTRACT}

This article problematizes the limitations of State-led urban planning for implementing the legal guidelines of a Right to the City in Brazil, focusing on the potential of political practices undertaken by marginalized communities. It claims that these specifically insurgent practices are central to the construction of an inclusionary urban planning that aligns with the research strands of "Southern Urbanism" and/or "Counter-Hegemonic Planning". This analytical standpoint is grounded in an indepth case study of the "Raízes da Praia" settlement, where politically mobilized residents have occupied disputed private property on the coast of Fortaleza, Brazil. The authors are part of the Education Outreach Program in Architecture and Urbanism (ArqPET/UFC) at the Federal University of Ceará, and for three years have offered technical assistance and outreach academic services to

\footnotetext{
${ }^{1}$ Mestrado em Planejamento Urbano e Regional UIUC/2003. Doutorado em Arquitetura e Urbanismo UNB/2009. Pos-Doutorado no Departamento de Planejamento Urbano e Regional UIUC/2016. Membro permanente do corpo docente do Programa de Pos-graduação em Arquitetura e Urbanismo e Design - UFC. Universidade Federal do Ceará - UFC, Ceará - Brasil. ORCID Id: https://orcid.org/0000-0001-9268-5745 Lattes: http://lattes.cnpq.br/8637270011810347 E-mail:urbcla@gmail.com

2 Departamento de Arquitetura Urbanismo e Design - UFC. Universidade Federal do Ceará - Brasil. Lattes: http://lattes.cnpq.br/4652580939778898 E-mail: manuela.t.arias@gmail.com

${ }^{3}$ Departamento de Arquitetura Urbanismo e Design - UFC. Universidade Federal do Ceará - Brasil. E-mail: raquellrochh@gmail.com

${ }^{4}$ Departamento de Arquitetura Urbanismo e Design - UFC. Universidade Federal do Ceará / Bolsista do Programa de Educação Tutorial do curso de Arquitetura e Urbanismo - Brasil. E-mail: linagdf@gmail.com

${ }^{5}$ Departamento de Arquitetura Urbanismo e Design - UFC. Universidade Federal do Ceará - Brasil. Lattes: http://lattes.cnpq.br/3518233250065436 E-mail: raquellrochh@gmail.com

${ }^{6}$ Departamento de Arquitetura Urbanismo e Design - UFC. Universidade Federal do Ceará - Brasil. E-mail: virginiaevn@gmail.com
} 
community residents. Considering "public interest" as a struggle against spatial segregation and the peripheralization of low-income residents, the case challenges the so-called "participatory" institutional planning practices, with collective organizing practices informed by radical visions. The case illustrates that, in spite of an institutional planning initial openness for the dialogue, they have bended toward the maintenance of the current system of urban inequalities.

Key-words: Insurgent Practices. Right to the City. Southern Urbanism. Technical Assistance. Popular Planning.

\section{RESUMO}

O presente artigo problematiza a questão dos limites do planejamento estatal brasileiro em efetivar os direitos urbanos estabelecidos no marco legal vigente, e identifica potencialidades representadas pelas práticas políticas de grupos urbanos excluídos. Ao discutir a centralidade destas práticas insurgentes na construção de uma cidade democrática e inclusiva, o trabalho filia-se às abordagens teóricas do "urbanismo do sul" e do planejamento contra-hegemônico. A reflexão é possibilitada pelo trabalho de assessoria técnica e extensão universitária desenvolvida ao longo de mais de 3 anos pelo grupo do Programa de Educação Tutorial do curso de Arquitetura e Urbanismo da Universidade Federal do Ceará (ArqPET/UFC) à comunidade Raízes da Praia, uma ocupação politicamente organizada localizada na orla marítima de Fortaleza. O estudo de caso revela como a proteção do interesse público no desenvolvimento urbano - o combate à segregação sócio-espacial e a periferização das famílias de baixa renda - se deve muito mais às ações de resistência dos moradores excluídos do que ao apoio institucional da gestão urbana. Esta, a despeito de uma abertura inicial para o diálogo com os moradores, tende a conservar as estruturas de desigualdade vigentes.

Palavras-chave: Práticas Insurgentes. Direito à Cidade. Urbanismo do Sul. Assessoria Técnica. Planejamento Popular.

\section{INTRODUCTION}

Socio-spatial segregation is a defining feature of the city of Fortaleza, where a large part of the population does not have access to minimum housing conditions or basic urban services. Fortaleza is a typical Brazilian metropolis, resulting from a capitalist logic of spatial production guided by the interests of powerful economic groups closely associated to a real estate sector that is increasingly global and speculative (Harvey, 2015). As a result of this hegemonic capitalist urban development 
approach, we perceive the local state to be negligent in assuring minimum living conditions to all, thus compounding spatial inequalities. Within this context, one of the survival strategies of low income residents is to occupy vacant land. More than an act of survival, such housing occupations problematize an exclusionary urban development model. This article discusses the role of community practices as acts of resistance to hegemonic modes of urban production, highlighting the conditions under which it can be read as a political demand for a right to the city.

Drawing on a case study approach, this article analyzes the conflict over a land occupation located at the coast of Fortaleza, where residents named their community "Raízes da Praia" (beach roots). Although there are many stakeholders, resident practices are taken as the most important factor underlying the materialization of Brazil's constitutional assurance of urban inclusion. Politically mobilized by the Popular Council Movement (MCP), the practices of 84 families more effectively realized Brazil's democratic legal framework than institutional actions. That is to say, in spite of a progressive national legislation, and a democratically constructed and recently approved municipal Master Plan (Plano Diretor Participativo - PDP/2009), the strategies undertaken by local planning agencies did not guarantee resident tenure in this favored quarter of Fortaleza. The Raízes da Praia case illustrates how public interest-the struggle against socio-spatial segregation and peripherization of vulnerable residents - has not been protected by progressive plans and institutions, but by residents themselves.

The Raízes da Praia community has a rich history of 9 years of struggle for housing, developing practices they describe as "popular planning". To conceive of these practices as "planning" (popular or insurgent) is a political strategy, as it confers greater legitimacy to the actions of vulnerable social groups. It also acknowledges the existence of a legitimate collective organization beyond formal State institutions. Residents of Raízes da Praia have become highly capable of garnering political support and technical assistance, and conceiving of innovative forms of planning, including spatial production and public management. In order to assure their permanence on disputed land, residents have made use of innovative tools on several occasions, from the initial site occupation to decision-making processes related to housing unit design.

The article has the following structure. The first section articulates the theoretical concepts of planning, insurgent practices and technical assistance, which inform the analysis of the case study. The second section reviews the political-economic context of Fortaleza, and its influence on local institutional responses to urban informality and land occupations. The third section describes the history of the Raízes da Praia community, considering several relevant stakeholders involved in implementing the right to housing for residents over the last 10 years. Their practices have culminated in the current scenario of incomplete urbanization and insecure legal status. The fourth and last section 
analyzes the aforementioned facts, highlighting ways in which resident practices translate and materialize instances of popular or specifically insurgent planning.

We draw on mixed methods that include action-based research undertaken during three years of services to residents, specifically architecture technical assistance conducted through an academic outreach program. The authors have also conducted seven semi-structured interviews during the second half of 2018, with two MCP activists, two human rights' lawyers who have assisted the community, three residents and one legal consultant from the Brazilian Institute of Urban Law (IBDU). The interviews complemented field notes from participant observations of community meetings, public hearings, and collective deliberations with municipal representatives, in addition to cartographic surveys, and the document analysis of both media coverage and judicial processes.

\section{THEORETICAL FRAMEWORK: INSURGENT PRACTICES, POPULAR PLANNING, AND TECHNICAL} ASSISTANCE

In her introduction to the book Making the Invisible Visible, Leonie Sandercock describes a crossroads in urban planning theory at the end of 1990s (SANDERCOCK, 1998). For the author, neither of two dominant paradigms historically used to interpret the urban question is adequate for informing the challenges of planning cities at the end of the 20th century. On the one side, the Marxist paradigm positions planning as an prerogative of State actors whose actions maintain the conditions of capitalist urban production, frequently leading to inaction. On the other side, the modernist paradigm introduces an heroic narrative of planning, attributing every urban problem to a "lack of planning". From this perspective, rational, 'modern' modes of planning would inevitably lead to a parallel social order to be pursued by all social actors-or what critical Brazilian theory refers to as "technician planning" (SOUZA, 2006, LIMONAD, 2015).

Facing several challenges imposed by rapid urbanization processes of poor world regions (such as Southeast Asia and Africa), some researchers have undertaken efforts to overcome this theoretical crossroads. Watson (2016) affirms that researchers in Western or 'developed' cities who were influenced by post-modernists and post-structuralists migrated toward communicative and collaborative planning approaches, which build on Habermasian concepts of power and society. Nevertheless, for planning researchers informed by the reality of spatial exclusion, informality and incomplete urbanization that characterize cities of the Global South, collaborative planning' consensual and universal validity approaches do not seem to grasp the structural problems associated with these urban realities. As a Global South planning scholar, informed by her observations of the 
African urbanization process, Watson describes initial steps toward the creation of a new paradigm, or a "southern theorizing project" ( WATSON, 2016). Among the defining elements of such an initiative she highlights: recognizing the importance of place and context and using "situated" knowledge of what happens there to speak back to theory, and paying attention to global and historical forces which shape different parts of the world, questioning the unsupported universalizing of theory. This project is informed by notions of conflict (as opposed to consensus), informality, identity and ethnicity (WATSON, 2016).

These theoretical propositions adequately describe the Brazilian urban development process. From an institutional and normative standpoint, Brazil occupies a cutting edge position as it has devised innovative legal tools aimed at fulfilling the social function of urban property (ROCCO \& BALLEGOOIJEN, 2019). Since the 1980s, the Brazilian redemocratization movement has influenced urban policies and management throughout the country. It has institutionalized the claims of Rights to the City, acknowledging the limits of technocratic state planning practices, with the intention to expand planning actions to encompass social movements' demands. Yet, along with this movement to democratize planning practices, there has been a stronger movement of dismantling social welfare policies closely tied to economic restructuring, deregulation and privatization (FREITAS, 2017).

The diminished role of the state associated with neoliberal ideologies exposes the fragility of the modernist planning paradigm, which positions the planner as a technician who operates outside of the influences of the political world and is the owner of scientific knowledge. It requires the construction of a new planning conception, grounded in civil society practices instead (MIRAFTAB, 2012). The current reality of Brazilian cities reveals how planning "per se" should not be described as a panacea for all urban illnesses, although it eventually might contribute to improve general living conditions of residents. This, of course, depends on who decides, how and with what goals it is implemented.

It is not uncommon to attribute the causes of urban chaos and crises to a "lack of planning", since ultimately they are caused by broader political problems such as opaque decision making processes attentive to special interests and that leave behind the demands of the urban majority (LIMONAD, 2015). In this direction, several authors highlight the limits of traditional state planning practices, and investigate the promises of the political practices of vulnerable groups (i.e. LIMONAD, 2015; VILLAÇA, 2005; OLIVEIRA et all, 2016). In Brazil, it is not uncommon for collective actors to define their practices as "popular planning", as a way to legitimize the practices of "invisible/irrelevant" actors-such as residents of precarious informal settlements on urban peripheries - as city makers. Collective actions of under-represented socio-spatial groups can be important for guaranteeing the 
implementation of truly democratic and inclusive urban policies, and for illuminating new perspectives about the facts (MIRAFTAB, 2012; HOLSTON, 2008; SANDERCOCK, 1998).

Similarly to community actors, planning professionals can also assume new roles, using technical knowledge to promote collective autonomy to politically vulnerable groups (SOUZA Jr et al, 2019). In the field of Architecture and Urbanism this new modus operandi of professional practice began with the work of Santos (i.e. 1988), who describes the architect as a mediator, a translator of urban languages such as land use codes and standards, among several stakeholders. In 2008, the enactment of "Technical Assistance Bill (Portuguese translation)" protects the right of low income families to architectural, urbanist, and engineering services that would benefit their home. Even though the law lacks implementation, it has bolstered the efforts of socially-minded professionals. For example, since the approval of the bill, the Architecture Professional Accreditation Board (CAU) has agreed to fund related professional initiatives, thus universities have been obligated to expand their architecture curriculums to include community outreach programs. Thus "technical assistance" is not a mere professional service for a "beneficiary". Rather, as Kapp and Baltazar (2016) outline, the Brazilian policy framework understands technical assistance as a mechanism for architecture to help citizens become autonomous political subjects, aware of-and better equipped to transform - the structural inequalities of our cities.

The case of Raízes da Praia epitomizes the interactions between "technical assistance", "popular planning" and insurgent practices, and contributes to the Southern Planning Project by developing situated knowledge.

\section{INSTITUTIONAL STATE PLANNING IN FORTALEZA}

It is important to describe the case of Raízes da Praia within the institutional context of urban planning in the municipality of Fortaleza, where the governance of informal settlements has been shaped by two recent periods. The first period comprises the two-term administration of the leftist Workers Party (PT) mayor Luiziane Lins (2005-2012), followed by the center-left Workers Democratic Party (PDT) mayor Roberto Claudio (2013-2020). The latter, despite its roots in progressive politics, adopted a more conservative approach to urban management, specifically as relates to informal settlements.

The Raízes da Praia occupation movement was established in 2009, toward the conclusion of Luiziane Lins' first term. Compared to former administrations, Lins' created broader spaces of dialogue with housing movements. The Workers Party agenda was associated with the urban reform agenda, 
which was, at least on the level of discourse, hegemonic in the National political realm. The PT's Pluriannual Budget Plan, Participatory Master Plan, and the Participatory Budget initiatives revealed the willingness of this political group to support democratic decision making process (MACHADO, 2011). This approach is at the core of the Party's history of close alliances with popular movements and struggles, illuminating the willingness of local housing agencies to hear popular claims.

It is within this context that the strengthening of the local Housing Agency (HABITAFOR) resulted in the implementation of several housing programs and land tenure regularization initiatives during Lins' first term (HOLANDA, ROSA, 2017). At this time, the old technocratic approach to master planning was usurped by a more democratic process, with mixed results. For example, the federal "My House, My Life" housing program (MCMV) significantly increased the construction of new low income (social) housing for families earning less than 3 minimum wages (USD or EU/month), such as residents of Raízes da Praia. As elsewhere, the implementation of MCMV has increased the quantity of housing units, but has furthered the peripheralization of low-income residents and lowered the minimum housing standards for the peripheral estates produced, thus accentuating a perverse spatial segregation process (FREITAS \& PEQUENO, 2015). Since its inception, MCMV has consolidated all political efforts around diminishing Fortaleza's housing deficit, but abandoning several previously innovative experiences. In fact, it is fair to affirm that MCMV in Fortaleza has served as an alibi to justify the deconstruction of a previously existing democratic experiences, which were guided by a recognition of informal residents rights to disputed land in centrally located, high end neighborhoods, established in the Municipal Master Plan of February 2009.

The Raízes da Praia occupation started in August 2009. During its early years, Raizes da Praia's residents took some important steps towards tenure security, resulting from political negotiations with the local municipal housing agency HABITAFOR. The initial positive results can be partially attributable to the community's political visibility, collective action leading to the support of civil society and other social movements, and technical assistance from progressive architecture and planning professionals. The residents and their supporters were able to draw the municipal government into their land conflict, legitimizing their actions, and diffusing the conflict toward a somewhat favorable position. After two years of Raizes da Praia's occupation, in 2011, institutional support from HABITAFOR started eroding-even under the workers' Party administration.

Support for Raizes da Praia further eroded after the Workers' Party lost municipal elections in 2012, and Mayor Roberto Claudio took office in alliance with a political group closely tied to the State government of Ceará. According to residents, this shift intensified a previously existing movement of criminalization and stigmatization of their practices. Negotiations between the community and the formal landowners were interrupted, making it evident that the Municipal government was neglecting 
their cause. Residents felt that municipal government support was weak, and frequently elusive. They claim that the greatest obstacle to land regularization-and thus tenure security - was the location of the community on land that was disputed and coveted by powerful real estate stakeholders (CASTILHO, 2011). Thus, despite a previous erosion of PT administration support, the change in urban political regime to PDT reveals a clear distinction in political approach regarding the recognition of residents' rights between both parties.

According to local researchers (i.e. GOIS, 2018) the Claudio Administration is greatly influenced by the real estate stakeholders' lobby to (a) carry out public works, (b) loosen land use norms to meet their demands and (c) weaken social control mechanisms (such as participatory councils and Impact Assessments). HABITAFOR, which registered thousands of low income families to MCMV Housing program, has produced an insufficient number of housing units and timid incremental housing programs. This scenario reveals a disparity between urban and housing policies and concrete results under the PDT administration (LESSA, PINHEIRO, VERAS, 2017).

Neither municipal regime effectively disrupted an urban development mode associated with neoliberal governance, as both resorted to private sector dependency to supply essential services, consumers freedom of choice, flexibility, decentralization and participation (FREITAS, 2019). Nevertheless, a historical analysis reveals a clear movement of political de-mobilization of residents after the change in political regime in 2013.

\section{HISTORY OF THE OCCUPATION}

Low income communities located in the seacoast neighborhoods of "Serviluz" and "Praia do Futuro" are embedded in housing struggles and violent evictions in Fortaleza. An illustrative example of violent conflict over coastal land is the "Morro da Vitória" community in Serviluz. A significant part of the community was evicted in 2001 , in an episode with local repercussions. The violent removal of the occupation triggered a sense of awareness of rights among the families, and the need to mobilize and organize for a right to housing. As public housing agencies had not been able to meet the growing housing demands, some families saw a last resort in the occupation of one of several vacant plots close to Morro da Vitória, in Serviluz. According to Castilho (2011, p.51), they understood the act of occupation as a tool to build popular power, by not only meeting their immediate housing needs, but as a means of appropriating the city. 
A few years after the violent removal of Morro da Vitória, MCP (Popular Councils Movements) partnered with the Morro da Vitória residents' association to conduct a series of meetings to empower and raise awareness among evicted citizens who were denied their fundamental rights to decent housing conditions. These training meetings unfolded over about three years, and explored themes such as the nature of the MCP movement, the problems of vacant land, the rights and duties of occupants. The meetings provided a space for participants to dialogue about their dreams and will to fight for them. These meetings also aimed at preparing families to participate in the elaboration of the Municipal Master Plan, which was approved in February of 2009.

When it didn't work there (in Morro da Vitória), we spent three years teaching people to be able to occupy here later. Because we saw that the way they occupied it there wasn't ... if we didn't have an organization, we wouldn't occupy anywhere, and it wouldn't work anywhere. Then it was necessary for us to bring the people together, those who wanted and stayed with the MCP movement, those people we chose, who stayed and were trained during several meetings together. When the initiative was three years old, and we saw that the participants were ready, and really knowing what they wanted, that's when we occupied here. (Report by one of the interviewed leaders. Interview granted on June 22, 2016.)

The debates around the Municipal Master Plan have contributed to the development of political awareness in several informal communities of Fortaleza's coastal region, as many felt capable of conquering a larger political space. MCP has demanded a voice in the process of constructing the Plan, a process through which they have empowered several of their participants. During this process they have made several attempts to garner the support of municipal agencies for their immediate housing needs. Both "Morro da Vitória" associations issued notices, sent letters, and petitioned HABITAFOR on a frequent basis. They organized several protests and political mobilizations, and, as a result, they have been received by municipal agencies to discuss solutions to their needs, in hopes of reaching a satisfactory solution within the Brazilian legal system. According to resident interviews, as a result of an intense political mobilization process, and after having been informed that formerly evicted families were planning a new land occupation, the president of HABITAFOR confirmed commitment to helping residents find a suitable plot. Yet this promise was never fulfilled. 

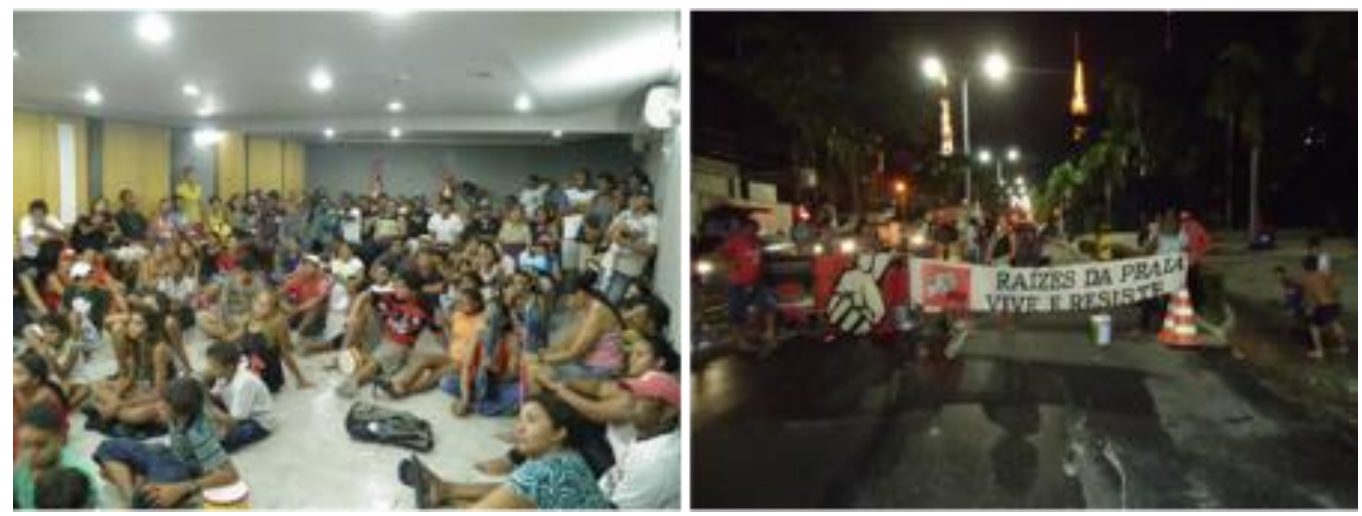

Figure 1: Documentation of community participation during the first days of Raizes da Praia occupation.

Source: Picture taken by residents

After realizing that the conversation with municipal agencies had only culminated in empty promises, a group of 80 families who participated in MCP training meetings decided to occupy an area of 10 contiguous private plots, located by the seacoast between Cesar Cals Avenue and Clovis Arraes Maia Avenue. Because the area remained vacant since its original subdivision 25 years ago, it did not fulfil its social function as mandated by the Brazilian Constitution. Following the initial occupation, families started the work of clearing and weeding the land, as well as measuring parts of the land that they would subdivide into plots to fit the shacks of each family. This is the genesis of Raízes da Praia community, the result of resistance to an urban policy that, despite appearing democratic and open to dialogue with families in need, did not respond to their imminent housing needs nor, for that matter, the Federal constitution.

Raízes da Praia, it comes from ... we had several meetings to choose that name, and we saw.. several names were mentioned, but when we heard Raízes da Praia, we saw that it had an end, a fundamental story, a fundamental end. Because Praia (beach), we live on the beach, most of the people who came here live close to the beach, and many people who did, and still exist today within the Raízes da Praia community, are fishermen. And the families of these people were fishermen in the past. And that, we call Raíz (root), as it were the fruits that were already rooted inside, both inside the meetings and the families we were forming, as well as outside, because outside there was fishing, which had their families, their children, their grandchildren who fished. So that allowed us to make this choice: the Raízes da Praia community. (Report by one of the interviewed leaders. Interview granted on June 22, 2016.) 


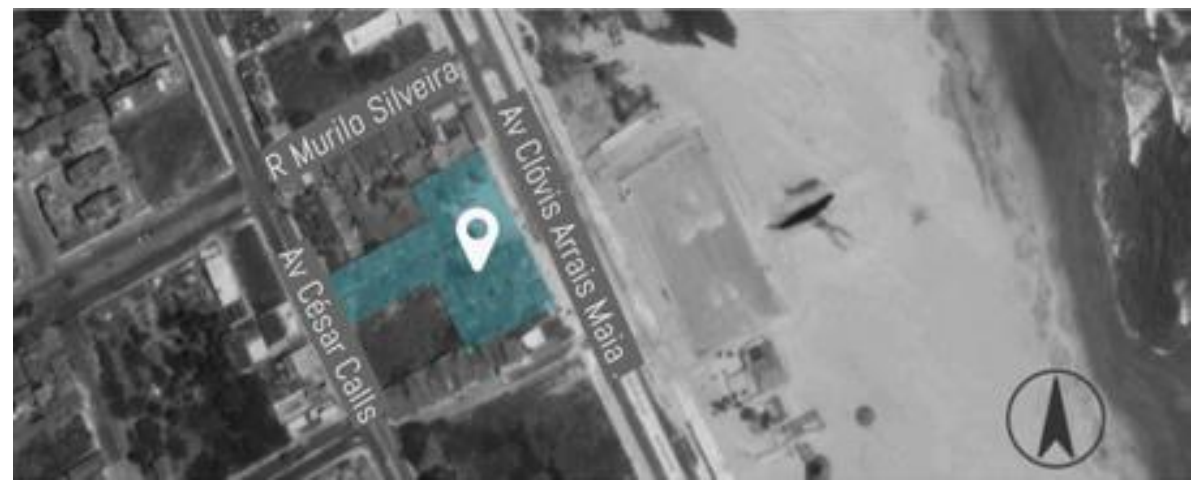

Figure 2: Location of the Raízes da Praia community on the coast of Praia do Futuro

Source: The authors (2018)

Since its initial settlement, Raízes da Praia residents have faced several attempts of forced removal, by a group of armed people who were hired by the supposed owner of the occupied land. Families have described occasions when they have guns to their heads, and when their houses were destroyed by bulldozers that they refer to as "militia". These violent episodes were the impetus to the construction of a support network, initially established by the Office of Human Rights of Unichristus University (EDH) and by the Office of Human Rights and Popular Legal Advice Frei Tito de Alencar (EFTA) of the Legislative Assembly of Ceará, and which is now made up of other human rights defense bodies, such as the Human Rights Commission of the Legislative Assembly of Ceará, and other social movements and mandates of parliamentarians supporting the occupation. Despite several criminal complaints that families were being illegally threatened with eviction, the supposed landowner, who belongs to a wealthy local family, was not charged. The following excerpt from an interview of a resident and MCP activist, describes these removal attempts.

So they were counting on their experience in frightening and threatening vulnerable families, because they would come - all hooded - screaming, threatening 'you will die for something that doesn't belong to you, you will leave, for better or for worse". So it was a psychological battle as well as physical, aimed at frightening us. Not to mention that some of us, like Teresa, spent days with a black car following her. So we were afraid to go around the corner, afraid to go and not come back. So we were always going out with one more person, because our fortress was inside the land, everyone was protecting themselves, the concern of not leaving the land empty, because we knew they were watching all the time, and that if there were few people there, they would come to 'let's get it out now'. The sadness of not being able to put on another piece of canvas, because if we did, they would come and say to take it out, because we had to leave everything open, they had to see what we were doing all the time, it was a psychological pressure 24 hours a day. There was a time when we wanted to close the shed, because it was very hot, they didn't allow it, they had to be watching us all the 
time. We went to the bathroom, we thought no, when we saw there was a security guard behind us, so it was a terrible pressure. (testimonies of occupants apud Castilho, 2011).

Residents described several illegal attempts at intimidation. For one week, there were daily attacks before dawn, forcing residents to gather and dialogue with the attackers about the legitimacy of the occupation and its peaceful character. Residents also recalled another episode when a group of armed henchmen occupied a portion of Raizes da Praia, with the intention of frightening residents into giving up on the occupation. This forced families to gather on the other side of the land, as a strategy to guarantee land tenure. Yet, it was only when a lawyer, a supporter of their cause, intervened at that dreadful moment that both parties were able to reach an agreement, and the henchmen left the land. The families signed an agreement with HABITAFOR, to not build permanent brick houses prior to the land's legal regularization. HABITAFOR representatives had already been involved in negotiations with the supposed owner, forcing him to withdraw the henchmen, and allowing families to build temporary shacks. Yet this deal only reinforced the extent to which urban managers wanted to avoid consolidating the community, thus maintaining the precarious housing conditions of the occupation.

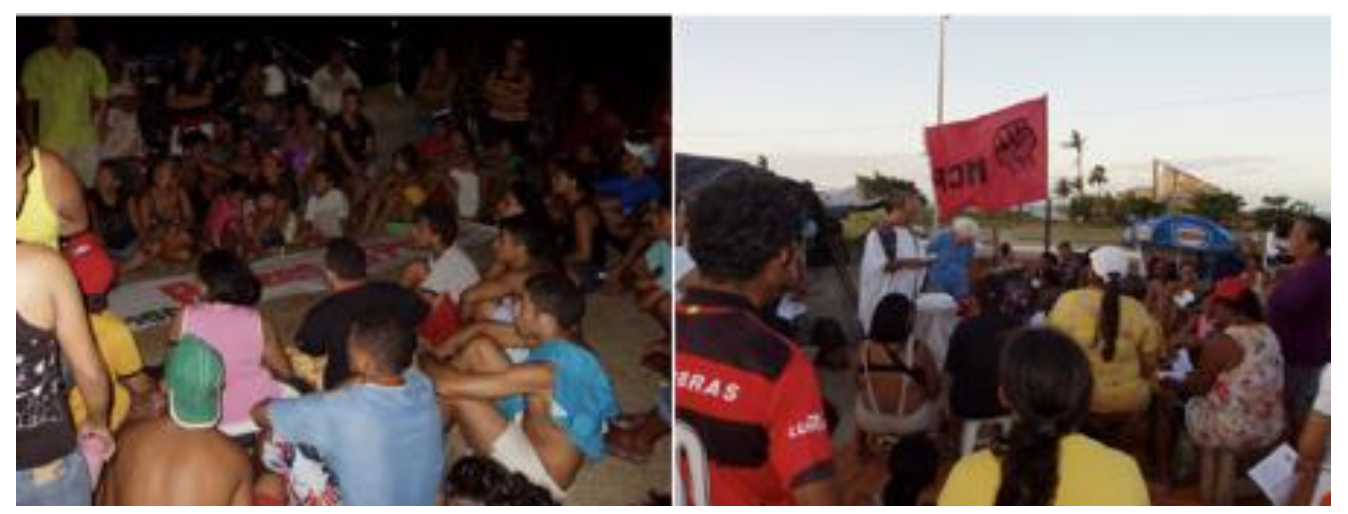

Figure 3: Documentation of the community settlement

Source: Digital community resources

It was only after these attempts at illegal eviction that the alleged owners sought legal action to repossess the property, on July 13,2009 , followed by a court order to repossess one of the property's ten lots in September of 2009. In response the judiciary granted an injunction for land repossession without assessing the extent to which the property did not fulfill its social function (as it had stood vacant for 25 years). This incident evidences that judicial decisions related to conflicts over private lands are still guided by an individualist - privatist interpretation of the Brazilian legal provisions that protect private property and possession, disconnected from the constitutional principle 
that protects human dignity (Castilho, 2011). A team from the local attorney Frei Tito's office, together with the Human Rights Commission of the Legislative Assembly of the State of Ceará, present at the time of the repossession order, mediated contact between HABITAFOR representatives and the bailiff. The intervention of the housing agency proved to be fundamental in the negotiation process for an injunction of non-compliance. Further, the diversity of people and movements present made it even more difficult to comply with the judicial eviction order that would imply the abandonment of people who would not have anywhere else to live, and the order was stayed.

Several interviewees attribute this initial victory to the community's capacity to organize. After this key moment of reversing the decision to repossess the Raizes da Praia property, residents followed up with the municipal government, demanding solutions for land regularization, and tenure security. In August of 2009, the occupation was recognized by the government, with the expropriation of one of the community's ten lots, and it was agreed that the municipal government would pay for the electricity used by the community. At the same time, a second lot remained in litigation and a third lot had not yet been claimed by the owner. Regarding the relationship with the municipal government during the occupation's early stages, a speech of one of the MCP coordinators is as follows:

When the occupation began, we achieved some institutional advances because there was already this process of negotiation and recognition from city hall. They saw the mobilization of the occupation, the political recognition, and that we were involving various actors. We managed to attract the city government to the conflict, and which defused the conflict. We're not leaving here, we're here because of you, several promises were not fulfilled, and so we have occupied.

In 2010, Habitafor proposed the inclusion of the community in a redevelopment and land tenure regularization project for the Serviluz neighborhood, called Projeto Aldeia da Praia. With the inclusion, HABITAFOR would also regularize Raízes da Praia. However, this project did not materialize and, soon after, another proposal was announced: the inclusion of Raízes da Praia families in the Minha Casa Minha Vida Program for subsidized housing. According to residents, HABITAFOR representatives claimed that the agency had made that land available for the program and, therefore, the community was obligated to accept the associated subsidy. With this option, a private developer would become the owner of the land and the families, through financing with Caixa Econômica Federal, would gradually pay mortgage installments for their allocated homes. At a regular community meeting held on September 11, 2010, the group rejected the proposal. The arguments presented reflected a fear that some properties would be taken over and sold to third parties. This would de-characterize the community's struggle and sacrifice because, according to the residents, had they opted for the market logic of the Minha Casa Minha Vida Program to begin with, they would have registered individually, rather than face the struggle to realize a collective right to housing (Castilho, 2011). 
In November 2014, the permanence of the Raizes da Praia community was threatened once again. Even though the municipal government had suspended the payment of electricity bills since January 2013, the Electric Energy Concessionaire (COELCE) decided to cut off the service supply. In response to resident complaints, the State of Ceará Public Defender's Office filed a Civil Action lawsuit, demanding that HABITAFOR and COELCE restore energy supply to Raizes da Praia, and that the municipal government allocate the land for use as social housing. The judgment of this action was issued in August 2017, requiring the Municipality to comply with the requirements of the aforementioned civil action. A month later, the Municipality of Fortaleza issued a request to suspend the preliminary injunction, which was monocratically rejected. The case was ultimately won by Raízes da Praia on the first count, however the process is still progressing, and there may still be three to four counts remaining.

In 2015, community members sought out a group of students from the Outreach Education Program (PET) of the Architecture and Urbanism course at the Federal University of Ceará (ArqPet UFC) to obtain technical assistance in the construction of housing units. Faced with government latency in granting formal land tenure to residents, they were considering breaking their signed agreement with HABITAFOR, and replacing their shacks with masonry houses. Residents were not looking for a finished design solution, but a participatory decision-making process, through which to arrive at housing options collectively. Between 2015 and 2017, ArqPet worked with residents to define proposals that incorporated individual and collective interests while meeting the population's ability to pay.

During the workshops ${ }^{7}$, residents were faced with two choices: organize housing units in ways that respect local zoning, which would require densification and thus tall buildings; or organize lowerdensity housing units outside of the zoning codes, sacrificing free and common areas but maintaining minimum levels of light and ventilation. The participants chose the second option, which would allow all families to keep a backyard and densify each dwelling individually. In the same period, in 2016, residents managed to formalize a Residents' Association, a precursor to initiating an adverse possession legal petition.

\footnotetext{
${ }^{7}$ For more information about the workshops and a description of the technical assistance activities conducted by ArqPet, see http://pet.arquitetura.ufc.br/2017/05/raizes-da-praia-resistencia-urbana-na.html
} 


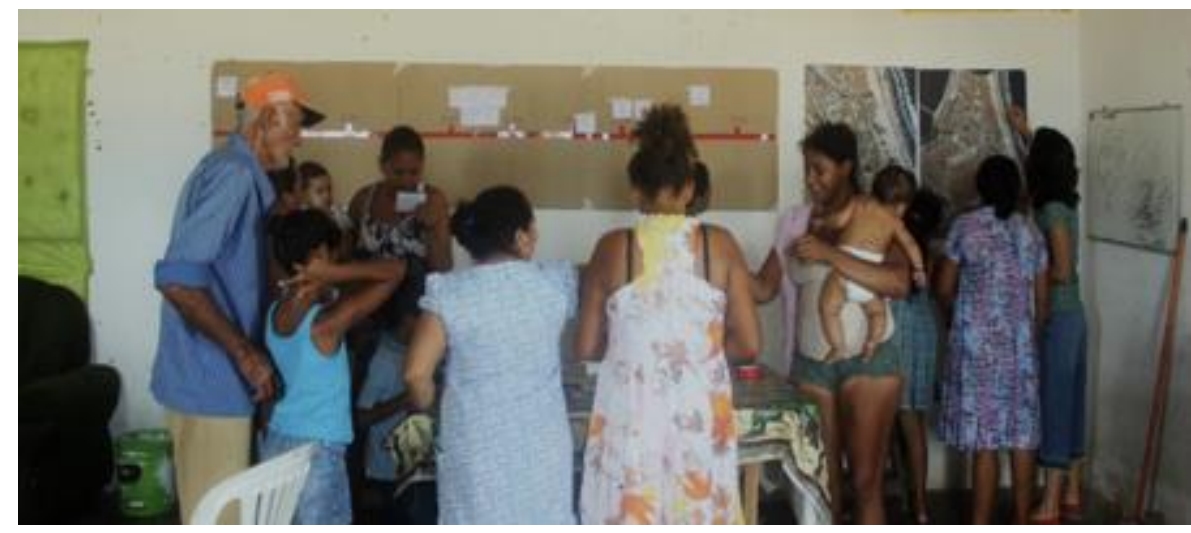

Figure 4: Workshop timeline

Source: ArqPet UFC
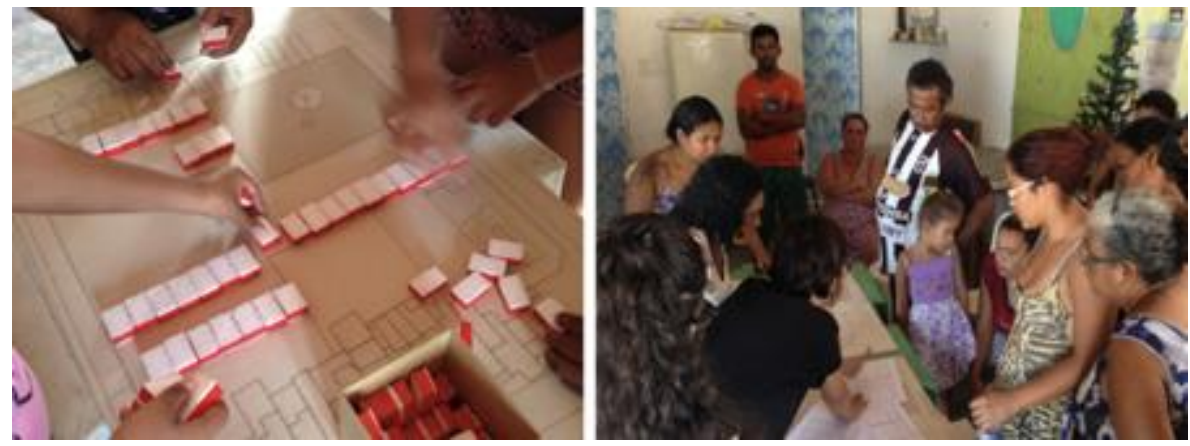

Figure 5: A game with models

Source: ArqPet UFC

In 2017, the Public Defender's Office of Ceará filed for a process of collective adverse possession, which claims ownership rights to lots $04-08$, and lots 14, 15, and 16 (Figure 6), on the basis that the community had occupied the land in excess of 5 years. Collective adverse possession, established in Art. 9 of the City Statute (Law No. 10.257, of July 10, 2001), holds that:

whoever owns as his area or urban building of up to two hundred and fifty square meters, for five years, uninterruptedly and without opposition, using it for his home or his family, will acquire the domain, as long as he is not the owner of another urban or rural property, making possible the division, by the judge, an ideal fraction equal to each owner, except in the cases where there is an agreement among the condominium members for a differentiated division of the fractions. Therefore, this modality presents a means of facilitating (land) regularization, reducing the time that would be used in individual adverse possession actions. 


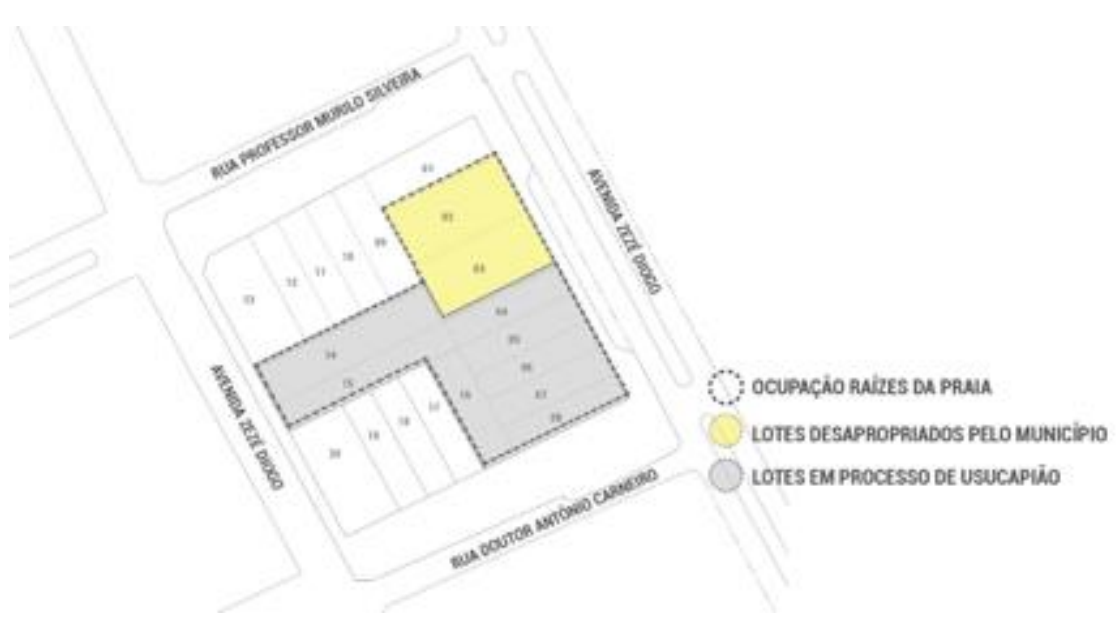

Figure 6: Platting the lots in the process of adverse possession

Source: The author (2018)

Over the past decade, residents of Raizes da Praia continue to live in precarious shacks and in extremely unhealthy conditions. In addition to being very small, with little or no ventilation and lighting, the shacks are made of ad-hoc sheet and board materials. The sanitary sewage system is black pits that drain into an open ditch, just meters from the beach, triggering disease and sickness among residents. During the rainy season, there are more cases of Dengue, Zika and Chikungunya. There are also cases of skin diseases and infections, which have bedridden residents. In an attempt to resolve this sanitation crisis, residents have contacted the city hall - through HABITAFOR - between 2016 and 2018 . When they do manage to schedule meetings, the agency's response is invariably a promise to take action that never materializes.

There's a giant hole in the middle of the occupation, when that hole gets full, it becomes a rotten mud filled pit full of mosquitoes, with everything you can imagine and we fought a lot with the municipality to at least plan the land so that we could improve the housing situation but they only gave us promises. (Testimony of a resident. Testimony granted on May 21, 2018.)

Throughout a history of struggle, residents of Raizes de Praia have consistently tried to reach agreements with the municipality to act legally, even as their claims were largely ignored. As a result, residents still haven't transitioned their shacks into masonry houses. However, the technical consultancy in architecture concluded that the community's sanitation issue must be resolved before any houses are extended or masonry dwellings constructed. Faced with this finding, the residents engaged in the support of the PET associated with the Environmental Engineering course at UFC, which resulted in a sanitary sewage project to complement the architectural project elaborated with resident 
participation. The architecture and engineering projects were taken to HABITAFOR, which would be responsible for executing the project, but without success.

With the advent of the COVID-19 Pandemic in March of 2020, the Raizes da Praia community suffered one of the first cases of COVID-related deaths in the city, a fact that is due to the absence of toilets, high density housing, and poor ventilation. As a matter of urgency, the city government had installed a fountain in May of 2020 so that residents would have access to drinking water. A week prior, the residents had achieved a fund-raising goal for a project that they would build to resolve the sewage and drainage issue, but without the consent of the public authorities. A few months ago, as a result of a public hearing held in May 2019, the Municipal Secretariat of Urbanism and the Environment issued a permit to approve this project. The Secretariat's response eliminated an important barrier to resident access to basic urban services, and increased the recognition of the occupation. Residents remain, however, in a condition of complete illegality. Over these 12 years of occupation, the lack of municipal accords with the residents contrasts with the concentration of investments that the Praia do Futuro region receives to bolster tourist activity.

\section{INSURGENT PLANNING PRACTICES}

This descriptive history of the Raízes da Praia Occupation demonstrates the incongruity between municipal public sector actions and federal legislation. A brief analysis of the occupation's history reveals that the actions of the municipality of Fortaleza contribute to the perpetuation of an illegal situation that disrespects the residents' constitutional rights. Faced with institutional obstacles that result from a lack of public power, popular planning was the solution for the direct application of Brazil's urban policy.

According to an EFTA lawyer and member of the MCP, Raízes da Praia is an emblematic case, as the dispute was symbolic, political and physical. The occupants achieved effective participation in the process, using their bodies as a shield for protection and for claiming their rights. The physical dispute was politicized by popular movements and advisors, mainly by the MCP, which was of extreme importance for the organization, discipline and resistance of the occupation during those years. The coordination of a social movement that had a history of struggle presented itself as an essential instrument for deepening political awareness among the occupants and developing the character of how they realized their fundamental rights. 
What ensures the permanence of residents on the land until today is their willingness to fight for their right to housing, a right that is rooted in the nature and extent of community organization prior to land occupation. The processes of political formation and confrontation prior to the occupation strengthened residents' capacity to cope with the public arena and with attacks by armed groups. It is interesting to observe through various resident testimonies that the attitude of occupying someone else's land was, initially, condemnable from a moral and ethical point of view. However, little by little, based on political formation processes, they began to perceive the need for housing collectively and as a structural problem, not an individual one. Gradually, the attitude of disapproval for occupying the land was replaced by bonds of solidarity among neighbors. Thus, the training processes, including those initially carried out for the development of the Participatory Master Plan of Fortaleza, made it possible for people to feel morally correct, because, for them, occupying land became a way of affirming their rights as citizens.

Society has always seen an occupation in a very discriminatory way, such that in an occupation there are only criminals, there are only people who are no good, because how could you occupy a space that is not yours? And in that sense we proved to them that we were not criminals, we were citizens fighting for decent housing. (Testimonies from residents apud Castilho, 2011).

Currently, community members feel represented by their Residents' Association, made up of a presidency and a 12-member board. The positions are elected and members are responsible for community organizing, mediating internal problems and creating political strategies. It is notable that the board is composed almost entirely of women. The community assembly, held monthly, is the space where collective deliberations and general community norms are constructed. The board is the community's most important organizational tool and its genesis in the movement's early days. The occupation began with a horizontal character in which everyone exercised the same actions, everyone had the same rights and duties, and decisions and strategies did not come from leaders, but from popular power. Although the residents' association has a different organizational format today, due to the need to formalize activities, the community preserves the characteristics and regulations defined during the occupation's early settlement period. The regulations shape a community selfmanagement system, based on movement dynamics and the level of coexistence. As reported by residents, criteria were defined for housing development and public participation in the Raízes da Praia Community: 
Those who occupy are those who have nowhere to live; they rent; they live with their parents and the house still does not belong to the person. They cannot sell or rent it. So you have to fight for it to be yours, no matter what. These things just can't exist...sale, you can't even think about selling, because if you think about it, we take it. Whenever a person leaves, when another person enters, they have to abide by these rules. When we decide to take someone out, then we have an assembly and put another one in the same place. (Report of one of the leaders interviewed. Interview granted on June 22, 2016.)

Among the local regulations, banning the sale of houses stands out. This is a problem identified in most urban occupations in Brazil, one that reveals the reproduction of the logic of the market for the sale of land in informal settlements. The rigidity of the prohibition of selling shacks represents a way to restrain the development of this logic inside communities, given that most intend to consolidate other types of values, based on the collective community that Raízes da Praia wants to become. Moreover, the prohibition of trading and consuming drugs and alcoholic beverages within the community is also notable. This regulation aims to preserve the lives of residents and avoid possible confrontations with gangs and the police.

No one has ever died in my favela; I'm proud to say that about my favela. No one has ever died there, there has never been a case of violence, of the police, because the residents still live well together, despite all the difficulties and dangers that Fortaleza presents (Testimony of a resident. Testimony granted on May 21, 2018).

Residents of the occupation have long had the dream of being a model community: a community organized around a co-constructed and horizontal development approach. It could have followed the path of neighboring informal settlements where people occupy a plot of land, divide the space into equal lots and build their own home. However, during the interviews with the residents and members of the MCP, the desire to be politically recognized and respected for maintaining an internal organization that impedes drug trafficking and urban violence is clear. The community also exemplifies that, without a union that fortifies coexisting pacts within informal settlements, there are clear external threats that can weaken existing social relations.

The Raízes da Praia Occupation also conditioned the political right. It not only conditioned but perverted the law (RODRIGUEZ, 2016), using normative standards to materialize precisely what, via traditional institutional means, had been violated. Raízes da Praia resulted from many innovative strategies, occupying an abandoned land tract 25 years ago, translating this act into the realization of the social function of urban property. This was one of the indirect forms of public policy implementation that does not correspond to the model operationalized by the municipal government. 
In addition, the case of Raízes da Praia does not just show how the effectiveness of property rights is redefined, but how land use and occupation standards can be reshaped through the city planning and management process itself. During the numerous architectural design workshops, the search for community autonomy was always evident. When the residents were faced with the decision to collectively challenge the land use norms, which did not allow for the construction of 84 units without adhering to the verticalization model promoted by the real estate market; rather, residents were intentional about rejecting a model that did not meet their needs. Even after several explanations by the group of architects and students, arguing that disobeying land use norms could undermine the legitimacy of their project and the occupation itself, residents remained steadfast and unanimous in their embrace of quality housing. It was at this moment that the technical team began to develop lower-density, horizontal design solutions, alternative to current regulations, strengthening the relationship of trust between the community and technical teams. From there, the product of the collaborative project was carried forward by the residents across all meetings with the government, as an element of legitimization. Thus, the autonomy to define the norms that govern community spatial production positioned residents beyond popular public participation. While the latter suggests residents who are invited to a process whose structure is defined by professionals or the State, autonomy implies processes orchestrated by residents, in which professionals and the State would be the (eventual) guests." (KAPP, 2012).

The executive and legal victories of the case of Raízes da Praia reveal an unprecedented moment in the struggle for housing in Fortaleza, which can be classified as outcomes of insurgent planning practices as conceptualized in the literature. Members of a low-income community appealed to the executive branch, which intervened in a case involving the implementation of the community's right to housing on private land, through the expropriation of one of the property's lots. Subsequently, given the discontinuity of negotiations and the latency of municipal power, the community wielded judiciary power which, through public civil action, upheld the struggle's legality and forced the executive power to comply with its responsibility. It is important to emphasize that, if collective adverse possession is granted, the Raízes da Praia community will be the first in Fortaleza to use this instrument to successfully obtain collective ownership. 


\section{FINAL CONSIDERATIONS}

Popular movements organized around struggles for the right to the city established new mechanisms for solving the housing deficit and reinforcing the need for citizens to achieve a level of material and radical democracy that guarantees structural and subjective conditions that can improve the survival of residents (KAPP and BALTAZAR, 2016). The failure of institutionalized means for realizing the right to housing, parallel to governmental support for actions that violate constitutional protections, gave rise to confrontations between residents of the Raizes da Praia community and the municipality around disparities between Brazil's legal-political system and the urban system actually being implemented in Fortaleza.

The community organization of Raízes da Praia was fundamental for constructing an autonomy that transformed the perspective of individuals who became political subjects mobilized around a collective conquest for their rights and to define the directions of state action. The acts of resistance organized by social movements constitute, therefore, the plural and critical exercise of democracy. In the case of Raízes da Praia, this exercise was materialized through popular planning that subverted the logic of dominant economic groups and their close dialogue with the state and legal power, preventing advances in the achievements of popular sectors, and repressing social movement actions.

The socioeconomic and political structure that subsumed the city of Fortaleza boycotts community organizations. The struggles of the so-called failed community of Raizes da Praia due to the lack of achieving a desired housing solution must be re-signified, especially compared to the numerous occupations that were quickly evicted from surrounding areas. These reveal a structure that disables and paralyzes the actions of residents living on the periphery and social organizations, narrows the breath of urban movements, their power to pressure, and ultimately their autonomy.

The construction of political power from the very organization and planning of the Raízes da Praia Community demonstrates that insurgent practices can be an effective and pedagogical way to concretely guarantee rights, and to build a new society, of another legal-political system, from the intensification of popular struggles. However, after three and a half years of technical support and coexistence, it was concluded that the actions of civil society, despite being fundamental for the transformation of their realities, will never be able to replace the competencies and social obligations that the state carries. Ultimately, the insurgent practices of the Raízes da Praia Occupation guided the planning of the place and contributed to an understanding of how vulnerable citizens can use breaches of liberal democracies to induce a rupture and create something new: the permanence of 84 low- 
income families on private property along the coast of a large Brazilian metropolis (FERNANDES \& FREITAS, 2020).

In the case presented here, both the residents and the technicians (architects and lawyers) assumed non-traditional roles. The former designated themselves "popular planners," while the latter set themselves up as advisors, using their expertise at the service of excluded groups. All distanced themselves from the ideals of popular participation and consensual planning, given that this had been applied in the first administration of Mayor Luizianne Lins, with few concrete results in the transformation of housing conditions. In response, the actors sought to advance in the direction of conflict, recognition of difference and structural inequalities, informing the theoretical project of "southern urbanism", or as defined in the literature, "counter-hegemonic planning".

\section{REFERENCES}

BALTAZAR, Ana Paula; KAPP, Silke. Assessoria técnica com interfaces. Encontro da Associação Nacional de Pesquisa e Pós-Graduação em Arquitetura e Urbanismo. Porto Alegre, 2016.

CASTILHO, N. M. O direito de resistir ao direito: A experiência do Movimento dos Conselhos Populares (MCP) na ocupação Raízes da Praia e os limites e possibilidades da afirmação constitucional do direito de resistência. 2011. Monografia (Graduação em Direito). Faculdade de Direito da Universidade Federal do Ceará, Fortaleza, 2011.

FERNANDES, J. D. B.; FREITAS, C. F. S. O Agir na brecha: o lugar das insurgências participativas.

Revista Políticas Públicas \& Cidades, v. 9, n. 2, 2020.

FREITAS, C. F. S; PEQUENO, L. R. B. Produção Habitacional na Região Metropolitana de Fortaleza na Década de 2000: Avanços e Processos. Revista Brasileira de Estudos Urbanos e Regionais, v. 17, n. 1, p. 45-59, 2015.

FREITAS, C. F. S. Undoing the right to the city: World Cup investments and informal settlements in Fortaleza, Brazil. Journal of Urban Affairs, v. 39, n. 7, p. 953-969, 3 out. 2017.

DOI:10.1080/07352166.2017.1328974

FREITAS, C. F. S. Insurgent planning? Insights from two decades of the Right to the City in Fortaleza, Brazil. City: analysis of urban trends, culture, theory, policy, action, v. 23, n. 3, p. 285-305, 2019. DOI: 10.1080/13604813.2019.1648030 
FRIEDMANN, J. Planning in the Public Domain: from knowledge to action. Princeton University Press. 1987. 471p.

GOIS, R. D. Planejamento e participação: o caso da LUOS 2016 e do Fortaleza 2040, Ano de obtenção: 2018. Tese de doutorado defendida no Programa de pos-graduação em Geografia da UFC. Fortaleza, 2018.

HARVEY, D. Os Limites do Capital. Boitempo Editorial. 2015.

HOLANDA, B. ; ROSA, S. V. 16 anos de Operações Urbanas Consorciadas em Fortaleza: um olhar a partir das diferentes gestões municipais e da adequação à legislação urbana. In: XVII ENANPUR Encontro Nacional da Associação Nacional de Pós-Graduação e Pesquisa em Planejamento Urbano e Regional, 2017, São Paulo: FAUUSP, 2017.

HOLSTON, J.. Insurgent citizenship: Disjunctions of democracy and modernity in Brazil. Princeton, NJ: Princeton University Press. 2008.

KAPP, S. Arquitetos nas favelas: três críticas e uma proposta de atuação. IV Congresso Brasileiro e III Congresso Ibero-Americano Habitação Social: ciência e tecnologia "Inovação e Responsabilidade". Florianópolis: UFSC. 2012.

LESSA, L. G.; PINHEIRO, V ; VERAS, F. F. M. . Encontro de comunidades e Observatório de remoções: experimentações de uma práxis educativa em Fortaleza. In: XVII Encontro Nacional da Associação Nacional de Pós-Graduação e Pesquisa em Planejamento Urbano e Regional, 2017, São Paulo. Anais do XVII Encontro Nacional da Associação Nacional de Pós-Graduação e Pesquisa em Planejamento Urbano e Regional, 2017.

LIMONAD, E. Muito além do jardim: planejamento ou urbanismo, do que estamos falando?. In COSTA, Geraldo Magela; COSTA, Heloisa Soares de Moura; MONTEMÓR, Roberto Luís de Melo. Teorias e Práticas Urbanas: condições para a sociedade urbana. Belo Horizonte: C/Arte, 2015. p. 71-102.

MACHADO, Eduardo. Planejamento Urbano, democracia e participação popular: o caso da revisão do Plano Diretor de Fortaleza (2003-2008). Tese de doutorado defendida no Programa de Posgraduação em Sociologia da UFC. Fortaleza, 2011.

MARINO, A. "Ocupas" e Insurgências na São Paulo do Século XXI. XVII ENANPUR, São Paulo, 2017

MAYER, J. G. M.; LOURENÇO, T. C. B. Belo Horizonte, cidade ocupada: o caso da ocupação Dandara. In: OLIVEIRA, F. L. de; SÁNCHEZ, F; TANAKA, G; MONTEIRO, P. Planejamento e conflitos urbanos. Experiências de Luta. 1. ed. Rio de Janeiro (RJ): Letra Capital, 2016. p. 305 - 338. 
MENESES, V. D; CARDOSO, D. R; ARIAS, M. T; LEITE, R. M; FREITAS, C. F. S. Planejamento urbano e autonomia na microescala: aproximações para um processo horizontal. Seminário URBFAVELAS 2016. Rio de Janeiro. Disponível em :

<http://www.sisgeenco.com.br/sistema/urbfavelas/anais2016/ARQUIVOS/GT4-159-199-

20161013234506.pdf >. Acesso em: 29 jun. 2018

MIRAFTAB, F. 2012. "Planning and Citizenship" in Rachel Weber and Randall Crane (eds.) Oxford Handbook of Urban Planning. Oxford University Press. Chapter 38, pp. 1180-1204.

MIRAFTAB, F. Insurgência, planejamento e a perspectiva de um urbanismo humano. Revista Brasileira de estudos Urbanos Regionais (Online) Recife, v.18, n.3, p.363-377, set.-dez. 2016.

OLIVEIRA, F. L. DE et al. (EDS.). Planejamento e conflitos urbanos: experiências de luta. Rio de Janeiro, RJ: Letra Capital, 2016.

ROCCO R. \& van BALLEGOOIJE, J.. 2019. "The Political Meaning of Informal Urbanization" in Routledge Handbook of Informal Urbanization. Edited by Roberto Rocco and Jan van Ballegooijen. NY: Routledge. Pp. 1-11.

RODRIGUEZ, J. R. Perversão do direito (e da democracia): seis casos. Revista Direito \& Práxis. Rio de Janeiro, v. 07, n.4, p.261-294. 2016.

SANDERCOCK, L. 1998 Introduction: Framing insurgent historiographies for Planning. In Sandercock, Leonie: Making the invisible visible. University of California Press. Berkeley, CA. Pp. 1:36

SANTOS, C. N. F. D. A cidade como um jogo de cartas. 1. ed. Niterói; São Paulo: Editoria Universitária EDUFF; Projeto Editores Associados, 1988.

SOUSA JUNIOR, J. G. DE. O Direito Achado na Rua: Introdução crítica ao Direito Urbanístico. Brasilia: Editora UNB, 2019. v. 9

SOUZA, M. L. DE. Social movements as 'critical urban planning' agents. City, v. 10, n. 3, p. 327-342, 1 dez. 2006.

VILLAÇA, Flávio. "As ilusões do Plano Diretor". Livro em arquivo PDF distribuído gratuitamente pela internet. São Paulo, edição do autor, ago. 2005. Disponível para download no endereço www.usp.br/fau/fau/galeria/paginas/index.html 
WATSON, V. Shifting Approaches to Planning Theory: Global North and South. Urban Planning, v. 1, n. 4, p. 32-41, 6 dez. 2016.

Trabalho enviado em 24 de julho de 2019

Aceito em 19 de fevereiro de 2021 